\title{
An Assessment of the Impact of Constituency Development Fund on Rural Development in Education and Health Sectors in Rufunsa Constituency, Zambia
}

\author{
Chrine, C. Hapompwe'; Mabvuto Nanias Tembo ${ }^{2}$ \& Elizabeth Zyambo ${ }^{3}$ \\ ${ }^{1}$ Lecturer; Cavendish University Zambia, Faculty of Arts, Education \& Social Sciences \\ ${ }^{2}$ Post Graduate Student; Cavendish University Zambia, Department of Development Studies \\ ${ }^{3}$ Head of Department; Cavendish University Zambia, Faculty of Business \& Information Technology \\ DOI: $10.29322 /$ IJSRP.10.08.2020.p104110 \\ http://dx.doi.org/10.29322/IJSRP.10.08.2020.p104110
}

\begin{abstract}
This study envisioned to empirically assess the impact of Constituency Development Fund (CDF) on rural development with specific reference to education and health services in Rufunsa Constituency, east of Lusaka, Zambia. The objectives of the study were: to assess central government's consistency in disbursing CDF fund to Rufunsa Constituency; to assess the impact of CDF in the provision of health and education facilities in Rufunsa constituency; and to assess the level of community participation in CDF funded projects in the health and education sectors in Rufunsa Constituency. The study adopted a descriptive analytical research design incorporating quantitative and qualitative methodological paradigms with the questionnaires and semistructured interviews as main data collection tools. The data analysis was performed through Statistical Package for Social Scientists (SPSS) for quantitative and content analysis for qualitative data. The sample size of the study was 109 respondents residing in Rufunsa Constituency, who comprised three (3) respondents (community members) from each of the ten (10) health facilities and ten (10) schools of the three (3) wards as beneficiaries; ten (10) health facility administrators; ten (10) school administrators, ten (10) health staff and ten (10) teaching staff. From the civic side, there were one (1) Member of Parliament (MP), three (3) ward councillors and five (5) CDF committee members. The study revealed that Government has not been consistent in the disbursement of funds as most of the school

On the other hand, the study found out that the factors accounting for the low level of community participation in CDF projects included lack of awareness and knowledge of CDF availability, lack of awareness about the right and opportunities for participation, inadequate information dissemination, poverty and poor community attitudes towards development participation and projects. The study concluded that rural development programmes are fundamental tools in improving the lives of people in the rural settings, hence the need for CDF programmes to be prioritised on the national agenda and be properly synchronised in governmental policies in order to mitigate glaring rural underdevelopment. The success of CDF as a rural poverty alleviation strategy can only be achieved with a decisive consideration of numerous factors, which include but not limited to; government consistency in the disbursement of funds and beneficiary participation in the sectors in question. Therefore, the study recommended that more civic education is needed to local communities to enable them make informed decisions and be actively involved in the entire process of the community projects. Furthermore, there is need for government's consistency in funding constituencies, the amount of CDF allocated to each constituency should be increased to adequately improve the health care and education service delivery by taking into account factors such as size of the constituency (geographical / demographic); levels of poverty; and the levels of development required in such constituencies.
\end{abstract} and health facilities under study had not received CDF funding in the past five years. Factually, for the period under review, the constituency as a whole received only twice (total of $\mathrm{K} 2$, $150,000.00)$ out of five times $(K 7,000,000.00)$ from 2016 to 2020 thereby robbing the constituency of over K4,850,000 deserved development fund. Besides, local communities and stakeholders were generally not involved in project identification, preparation, implementation, monitoring and evaluation processes in the health and education sectors as they were not knowledgeable and unware of CDF channels, sources, quantity and frequency of disbursement. Ultimately, the study findings demonstrated that CDF in Rufunsa has not played a significant role in health and education services delivery as poverty levels, illiteracy, mortality rates, inequalities and underdevelopment levels were still on the high side. Medical equipment, ambulance services, mortuary facilities, health centres, classrooms, computers, reading materials, health and teaching staff were acutely in short supply.
Index Terms- Assessment, Constituency Development Fund, Impact, Education \& Health Sectors.

\section{INTRODUCTION}

$\mathrm{T}$ he world at large deem education and health sectors to be primarily basic human rights and the basis upon which to build peace, harmony, national progress and sustainable development (UNESCO, 2018). Todaro and Smith (2015) also stress that health and education are very important in fostering socio-economic development in both developed and developing countries. They are important ends in themselves (Todaro \& Smith, 2015: 359). Education specifically provides people with skills and competencies that allow individuals to perform productive roles; more literate and skilled labour force is likely to yield more returns on investment. Health care on the other hand, 
makes the people sound both in mind and body as they undertake what education provides. Thus both health and education promote social development and have strong links to poverty reduction especially in rural settings (Todaro, 2011: 359, UNESCO, 1997). United Nations Economic and Social Council (UNESC) further illustrates that development in general aims at changing social structures, popular attitudes, and national institutions; the acceleration of economic growth, reduction of inequality as well as the eradication of poverty (UNESC, 2018). This profound conception is equally posited and heralded by the Southern Africa Development Community (SADC) - a regional body to which Zambia subscribes. However, poverty and underdevelopment in most less developed countries have remained to be the major resounding threats to the effective and efficacious operationalization of these two social-based sectors despite their significance. Poverty is multidimensional and includes factors other than income (factors like education, health, politics, and society, vulnerability which ultimately lead to poverty). While poverty affects people in different ways, for sustainable development to be present, on the other hand, it requires meeting people's basic needs and fulfilling any opportunity of every aspiration for a better life especially for the rural people (Olinto \& Uematsu, 2010).

In the light of the foregoing and in order to address the question of rural development and rural poverty, African countries have continuously emphasized on the role of health and education as a means to social and economic development. For rural development to meet sustainable development, it requires special resources and institutions such as health and educational facilities that will fulfil people's aspirations for a better life. In the process of making these institutions present and functional, rural people have to be involved in the development of their respective communities (Pellissery, 2012: 222-225) for the sustainability thereof. In actualising this brilliant vision, Zambia's National Assembly in 1995, made a historic decision to make mandatory the allocation of funds to respective constituencies represented by members of parliament as a model of ensuring decentralised development from the lowest unit of society (GRZ 2006b:1). This annualised funding came to be termed as Constituency Development Fund (CDF) created through an act of parliament in 1995 (GRZ 2006b: 1). The rationale behind this initiative was to provide members of parliament and their constituent communities with the opportunity to make choices and implement projects that maximize their welfare especially in the areas of health and education. This fund was established mainly to assist fight poverty through the implementation of development projects at the local level and particularly those that provide basic needs such as healthcare, education, water, agricultural services, security and electricity (GRZ 2006: 2), among others.

Against this background, this concept paper was purposed to investigate the extent to which the CDF sent to these constituencies meet the stated blue prints with Rufunsa District as an epicentre of the study.

\subsection{Problem Statement}

Health and education still remain pertinent to the socioeconomic development of any community especially rural communities (Todaro, 2011: 359). In 1995, the Government of Zambia introduced Constituency Development Fund (CDF) as a tool to initiate projects in different sectors aimed at reducing poverty levels as well as improving rural lives (MoLGH, 2006). This endeavour of improving efficiency and utilization in health and education facilities and service delivery was to be carried out in partnership with faith-based organisations and NonGovernmental Organisations like the UNISAFE, Churches Health Association of Zambia, World Vision amongst many others which are supporting health and education service delivery in the constituency with over 51,000 human population. In the health sector, part of CDF is intended to help in building health centres or posts, maternity wards, mortuaries, mothers' shelters among others while in the education sector CDF is expected to help make accessible and available educational infrastructure like physical educational facilities, sanitation blocks, science and computer laboratories, classroom blocks and classrooms as well as libraries. Although such infrastructure and facilities aforesaid are said to have been constructed or put in place, anecdotal evidence indicate that they have not all been funded by $\mathrm{CDF}$ and that the improvements (if any) in the lives of people cannot be attributed to CDF. Over and above, the number of health and educational facilities available are far less than the demand of the population as beneficiaries despite the annualised disbursements of the fund for such community-based developmental projects. Since the enactment of the CDF fund in 2005, no systematic and organised studies have been done to thoroughly investigate the phenomena in the subject matter area to which relevance this empirical study will be.

\subsection{Study Objectives}

(i) To assess central government's consistency in disbursing CDF to Rufunsa constituency and the challenges inherent in its application.

(ii) To assess the level of community participation in CDF funded projects in the health and education sectors in Rufunsa Constituency.

(iii) To assess the impact of CDF in the provision of health and education facilities in Rufunsa constituency.

\section{THEORETICAL REVIEW OF LITERATURE}

\subsection{Rationale for Constituency Development Fund (CDF)}

Zambia has 156 constituencies dotted country-wide and each represented by a Member of Parliament elected every after five years. In 1995, the Constituency Development Fund (CDF) was initiated in Zambia with the purpose to provide local authorities with discretionary funds whose utilisation was solely for the provision of social services such as education, health, water and sanitation, agricultural services and other ancillary benefits to the community. As this fund was envisioned to be purely for community service, its utilisation was expected to occur within a socially inclusive participatory framework to all community members. Against this background and in a hope to consolidate the fund's rationale, the Government of the Republic of Zambia through the National Assembly enacted an act of Parliament on $23^{\text {rd }}$ December 2018 which would guide the disbursement, management and utilization of the fund. Act No. 11 of 2018 of the Laws of Zambia states: 
"An Act to provide for the management, disbursement, utilisation and accountability of the Constituency Development Fund established under the Constitution; establish Constituency Development Fund Committees in constituencies and provide for their composition and functions; and provide for matters connected with, or incidental to, the foregoing. "

By this act of Parliament, it became categorical that the constituency development was national and legal matter which required adherence and compliance by officers in -charge to public finance management ethos in funds utilization. Kaduuli (2008) affirms the importance of CDF, "CDF was introduced within Zambia's wider decentralization drive as a public fund to finance development projects at the constituency level through elected Members of Parliament". Therefore, the fund is designed to actively engage the local citizens on their priority needs. It is in this vein that the fund holds strong opportunities in poverty reduction and national development if well managed. These projects have a great influence in the quality of life of rural people especially where poverty is over $70 \%$ and they include education and health as priority amongst others.

CDF is an increasingly central fund in national development and plays a key role in rural development as it is situated within the local government framework and was set up by the government to mitigate poverty and harmonize the spread of development throughout the country. According to Chileshe (2011), CDF is one of the most significant transfers disbursed annually to the 156 constituencies. In 2006, the budgetary allocation for CDF was approximately US\$ 13,000 per constituency and had risen to approximately US\$200,000 per constituency in 2012 (National Assembly of Zambia, 2012). Since 1995, all the constituencies in Zambia have been eligible to receive the $\mathrm{CDF}$ funds (Ministry of Local Government and Housing, 2006).

\subsection{Rufunsa District}

Rufunsa is one of the newest districts in Lusaka Province which was declared by President Michael Chilufya in 2012. It is located in the eastern side of the province and is largely a rural district. The district has 24 public health facilities ranging from the health centres to the sickbay. In terms of education, the district has 11 primary schools and 3 secondary schools. Politically, the constituency has three wards, namely: Mwachilele, Nyangwenya and Bunda Bunda, each headed by a Councillor with 1 Member of Parliament as head of Council. For development purposes and pursuant to the Act No. 11 of 2018, the constituency has a 5 CDF committee members to co-ordinate development projects with the communities. However, it must be noted that Rufunsa constituency has no district hospital. Over and above, the district as a whole has over 51,000 people as population (CSO, 2010).

The foregoing demographic analysis of the health and school infrastructural statistics relative to available infrastructural space clearly demonstrates an already troubled situation in terms of education and health service delivery and requires liberation by way of infrastructure and other essential resources to match the growing demand.

\subsection{Constituency Development Fund and National Development}

CDF is meant to socio economically develop societies or the nation as a whole. Apart from the objective of poverty reduction, $\mathrm{CDF}$ is also aimed at enhancing people's participation in decision making processes, promoting good governance, promoting transparency and accountability (Francis et al. 2009: 11). In this framework, Members of Parliament (MPs) and local governments are assumed to be the primary agencies of providing social services to communities. Nonetheless, forms of CDF differ in terms of the amount, allocation principles and utilization. CDF is meant to respond to immediate, short-term community development needs and ensure that rural development spreads evenly throughout the country. However, unlike other development funds that filter from the central government through larger administrative organs and bureaucracies; funds under CDF program go directly to the local communities (NAZ, 1994: 1053). This gives local people the opportunity to participate in establishing local projects like health and educational programs which are perceived as the main challenge facing the rural local communities (Kimenyi, 2005).

In the recent past, Zambia made education and health services 'free' in order to bring them as closer to the families as possible and thus meeting the health and education needs of the Zambian people. Despite all these efforts made by the ministry of health and education, the health and education sectors have continued to face several challenges and constraints in terms of equity, accessibility, affordability, efficiency and effectiveness. Notably, rural communities and poor urban households have continued to have lesser accessibility and availability of quality health and education facilities and services. This is confirmed by the fact that people have to cover long distances in order to access health and education facilities or services. Other than the above, they also experience a lack of medicines, and high costs of living.

Nonetheless, this set of accessibility, availability and affordability constraints cause the poor communities especially in rural areas not to utilize these health and education facilities and services (Owino, 1997). Therefore, there is need for deeper understanding in terms of the impact CDF has played in the health and education sector to foster rural development as there is often misuse of resources allocated to the running of these funded projects because of lack of accountability, transparency, efficient financial supervision and participation by the target communities (Theil et al. 2007). This lack of accountability and transparency eventually paralyzes projects' facilities and service delivery. The Vice President of the Republic of Zambia, Ms Inonge Wina, confirms to the above, as she bitterly complained about the misuse and lack of monitoring of constituency development funds, which has contributed to poor workmanship (Zambia Daily Mail, 2016). It is with this background that the study seeks to investigate the impact of CDF on health and education sector in fostering rural development in Rufunsa Constituency between the years 20142019. The paper also investigates the extent to which these services are available and accessible by rural people at the community level through these members' participation.

Educational institutions are mandated to use education as a tool for social transformation. The success of a school is measured by the quality of input factors and the students it produces. The success of any educational institution is measured by the 
performance of its students in both academic and non-academic tests and this is a product of available infrastructure. Quality education is the hallmark of the MoGE in Zambia and resonating with and aligned to these philosophical / pedagogical conceptions, the vision of the Ministry of General Education (MoGE) is to provide, "Quality, Lifelong Education for all which is Accessible, Inclusive and Relevant to an Individual, National and Global Value Systems" (MoGE, 2019). Motifs of equity, accessibility, quality, relevance, inclusivity, lifelong learning, therefore, must be the guiding principles in developing any education system, platform, curriculum, intervention or philosophy in order to sustain these fundamental blue prints for human and national development. On the other hand, the none availability of proper healthcare systems impair any meaningful progress in the education sector.

\subsection{The Concept of Rural Development}

Rural development, has no universally accepted definition. The term is used in different ways in vastly divergent contexts. It connotes overall development of rural areas with a view to improve the rural quality of life. In short, rural development deals with multi-sectorial issues such as infrastructure, health care, hygiene, education, environment, water and sanitation, food security, governance as well as local income generation. Thus, rural development is a process that aims at improving the standard of living of the people living in the rural areas (Ogao, 2018).

With the result that rural development has the provision of social institutions such as education and health that could provide the catalyst to transform the rural areas, rural development may also be seen as an ideology and a practice because in essence it may imply a broad re-organization and mobilization of rural masses in order to enhance their capacity to improve their lives and with changes consequent upon this. Hitherto, rural development aims at improving the livelihoods by implementing comprehensive development projects, programmes of strategies for rural areas where a majority of people in poverty live. Rural development can also contribute to reduce poverty in urban areas by reducing excessive population influxes from rural areas.

According to the World Bank (2001a) in their paper Rural Development Strategy, there is an attestation that rural development must be clearly designed to increase rural production. Thus, there should be improved food supplies and nutrition, together with basic facilities and services, such as health and education. Subsequently, this not only directly improves the physical quality of life of the rural poor, but can also indirectly enhance their productivity and their ability to contribute to the national economy. Therefore, in this study, rural development ensures that social inputs and welfare facilities and services are developed using constituency development funds; these include physical inputs (such as the provision of feeder roads, safe water and rural electrification), social inputs (namely health and educational facilities and service) and institutional inputs such as credit facilities, agricultural research facilities, rural expansion services among others.

\subsection{Legal Framework, Management and Utilization of CDF}

The 2018 Constituency Development Fund Act No. 11 (2018) provides the framework on the Principles of management, disbursement and utilisation of CDF Fund. Act 11 goes further to explain the roles and duties of Minister/s relating to Fund,
Constituency Development Fund Committee, Functions of Committee, and the approval of the project. The CDF Fund shall be disbursed under the direction of Constituency Development Fund Committee constituted as per part II of the Act. The CDF Fund consists of monies appropriated by Parliament for the purposes of the Fund. The monies received by way of grants, fees, council contributions or donations should be used for purposes of the Fund specifically intended for funding projects.

All unutilised funds shall remain in the constituency account by the local authority and investments shall not be permitted elsewhere, except for funds meant for a project that is cancelled or discontinued. The Act further provides for the formation procedure and the operational structures to oversee the implementation of the fund. The Act also provides for how the CDF projects shall be identified, the number and type of projects to be funded.

And finally, Act 11(2018) Part IV extrapolates the penalties of the Fund misuse by stating that, any person who misappropriates funds or assets from the constituency, or assists or causes any person to misappropriate or apply the funds otherwise than in the manner provided in this Act, commits an offence and is liable, on conviction, to a fine not exceeding five hundred thousand penalty units or to imprisonment for a term not exceeding five years, or to both.

This law provides some greater degree of protection of the fund against embezzlement by disgruntled persons in the course of duty and is also instructive on the need for community participation with regard to activities of the fund.

\subsection{Theoretical Underpinning}

This study was guided by sustainable rural development theory that is hinged on two models or approaches. The two models are Rural Endogenous Development approach (IAMO, 2007; Hobo, 1996) and Participatory Development approach (JICA, 2004:179). These two models opine that sustainable rural development has four development objectives that need to be put in perspective for improving rural lives. These objectives being (JICA, 2004:180):

- Improvement of economic capabilities of rural people i.e. agricultural income improvement, non-agricultural income improvement, improvement of industries and development of infrastructures.

- Improvement of human capabilities, which entails general health improvement and development of educational standards.

- Improvement of protective capabilities of rural environment, which is conservation of natural environment and natural disaster prevention measures.

o Improvement of political capabilities; which encompasses the improvement of general political capabilities. This implies decentralization and improvement of policy-making capabilities leading to rural community participation in projects that foster rural development.

The foregoing theoretical tenets are of paramount importance in pursuing socio economic development especially in less developed countries where majority people live below the poverty datum line. There is need to re-organize and re-orient the development process in order to guarantee decency, dignity and self-esteem to many rural dwellers as per the prescriptions of these 
two models. There is no doubt that the development of the rural areas would also spread to the whole country. For the Zambian set up, the transformed and industrialised agricultural sector hold greater potential for this trajectory if properly invested into and incentivised.

\subsection{Conceptual Framework}

A conceptual framework refers a researcher's perception of the relationship between variables in the study and shows the relationship graphically or diagrammatically (Mugenda and Mugenda 2003). The conceptual framework of this study is illustrated in Figure 1 below showing the relationship between various variables related to success in poverty alleviation in rural areas, and how sustainable Heath and education have been impacted after the initiation of CDF in Rufunsa constituency.

$$
\text { Independent Variables }
$$

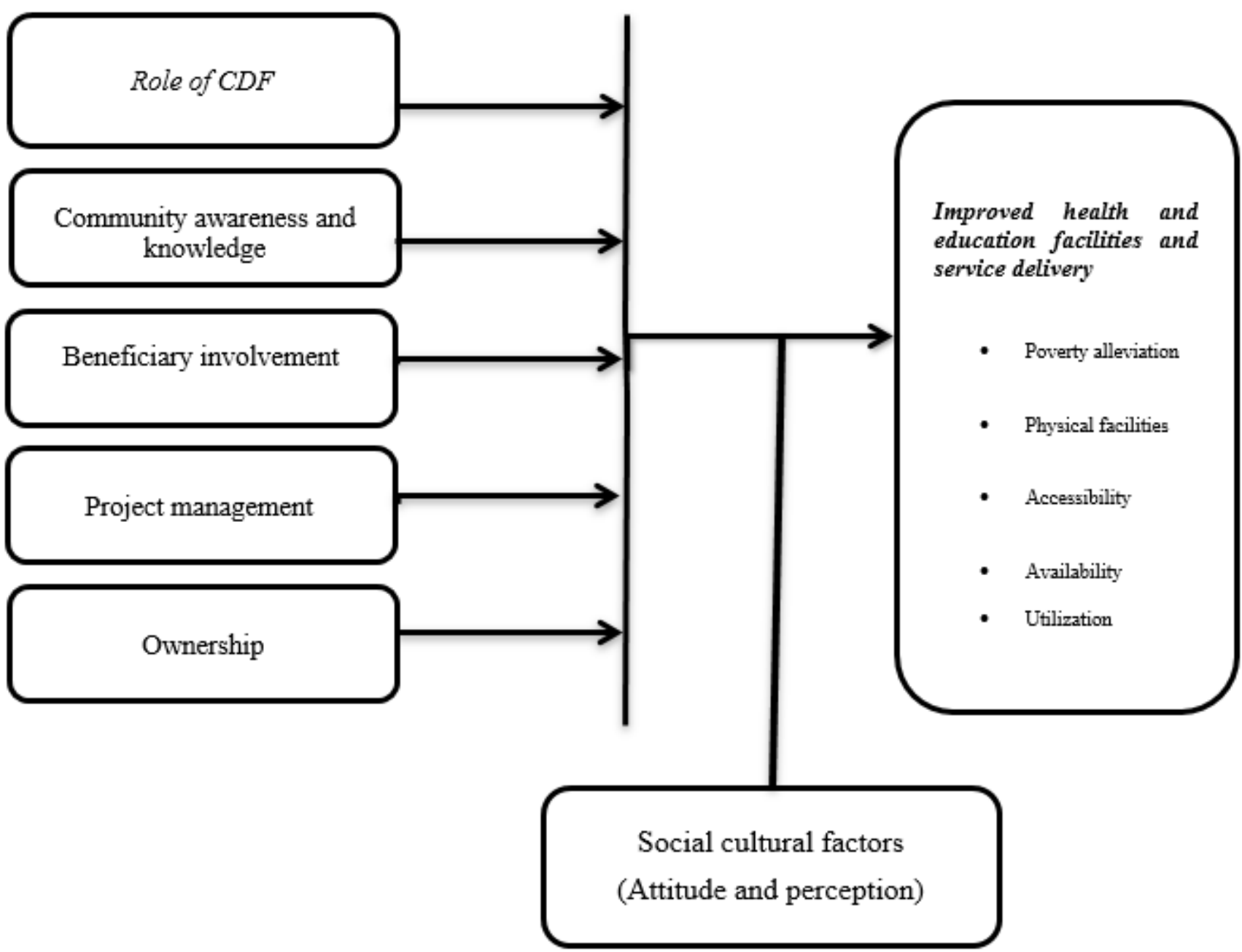

\section{Source: Author's Construction (2020)}

Figure 1: Conceptual Framework

\section{Intervening Variables}

Among the facilities CDF can help in providing in the education sector can be classroom block/s, science laboratories, water and sanitation, libraries, computers, electricity connection, school land and transport. In the health sector, CDF can help in providing ambulance services, drugs, health equipment and infrastructure. This can only be attained if there is consistent disbursement and correct application of the fund; community awareness and knowledge; beneficiary involvement; effective 
project management, and project ownership by the beneficiaries. These independent variables affect the dependent variable, which are improved health and education facilities thereby leading to poverty reduction, accessibility and availability of improved service delivery and quality of life. However, better and improved delivery of education and health facilities could also be affected by other factors like political interference from area leaders, community attitude / perception, socio cultural factors like early pregnancy which could lead to school dropout and health status of learners among others. These are captured as intervening variables.

Thus in summation, it is worth noting that, several rural development programs have failed to achieve their desired impact, goals and objectives due to poor organization and implementation strategies. Accordingly, relevant field methodologies that call for effective management of CDF funds especially in the health and education sectors have been inadequate in allowing maximum availability, accessibility and utilization of local rural resources (Kerote, 2007). Kerote further confirms that the CDF committees in rural constituencies do not fully understand vital components of project identification, management, implementation, monitoring and evaluation (Banda, 2019).

\section{METHODOLOGY}

The study adopted a descriptive analytical research design incorporating quantitative and qualitative methodological paradigms with the questionnaires and semi-structured interviews as main data collection tools. The target population is the totality of all the individual people or objects that possess the characteristics or qualities that are of interest to the researcher (Liu et al., 2014). This study targeted health and education institutions in Rufunsa Constituency. In the health sector, the target comprised all the twenty-four (24) public health facilities ranging from the health centres to the sickbay as beneficiaries of the CDF and the twenty-four (24) health facility administrators while in education the study targeted eleven (11) primary and 3 secondary schools with their fourteen (14) head teachers, which are found in the three wards. The study also targeted one (1) Member of Parliament, three (3) ward councillors from Mwachilele, Nyangwena and Bunda Bunda Wards, five (5) CDF committee members, senior employees and the beneficiaries of the implemented health and education projects / services in the constituency. The sample size of the study was 109 respondents residing in Rufunsa Constituency, who comprised 3 respondents (community members) from each of the 10 health facilities and 10 schools of the three (3) wards in as beneficiaries; ten (10) health facility administrators; 10 school administrators, ten (10) health staff and ten (10) teaching staff. From the civic side, there were one (1) Member of Parliament (MP), three (3) ward councillors and five (5) CDF committee members. Education and health institutions respondents completed questionnaires while civic personnel were interviewed. Purposive sampling was used as a technique to determine education and health institutions' respondents along with civic leaders and service beneficiaries. The data analysis was performed through Statistical Package for Social Scientists (SPSS) for quantitative and content analysis for qualitative data. The researcher personally administered the said instruments on a spot-basis to avoid misplacement, and observed a high degree of ethical standards throughout the study process.

\section{ANALYSIS AND DISCUSSION OF FINDINGS}

\subsection{Central Government's consistency in disbursing CDF to the Health and Education Facilities}

The impact of CDF on the health and education sectors in fostering rural development and service delivery greatly depend on the amount of money the health facility and education has received and the central government's consistency in disbursing $\mathrm{CDF}$ to constituencies especially those in rural areas or just developing. In this study, the key informants, the MP, Ward Councillors, Council Chairperson and staff were requested to state how consistent the central government has been in the disbursement of CDF funds allocated to the health and educator sectors in the constituency. The same key informants were also asked to state the annual amount of CDF allocated to their constituency in the past five years. According to the MP, the annual average amount of $\mathrm{CDF}$ money allocated to each constituency in Zambia either rural or urban was $\mathbf{K 1}, 400,000$ per constituency. It was equally confirmed that Rufunsa as a constituency had only received $\mathbf{K} 2, \mathbf{1 5 0 , 0 0 0}(\mathbf{3 1 \%})$ in the past five years instead of $\mathbf{K 7 , 0 0 0 , 0 0 0}$, broken down as K750,000.00 in 2016 and $K 1,400,000.00$ in 2018. This record corroborated with the Council Accountant's financial records.

According to the MP and some Ward Councillors, the annual CDF received by the constituency in 2019 amounted to K1.4 million and had not yet received any CDF for 2020 . However, it was noted that most of the health and education administrators were not aware of the amount allocated to their facilities. This was attributed to the fact that almost $90 \%$ of the health and education facilities had not received any CDF funding for the past five years. Most of these administrators lamented that they had been applying for CDF but unfortunately they were not being considered. And the researcher observed that many health and education related projects were in incomplete state necessitated by the lack of funding allocation to respective sectors.

The key informants further stated that the constituency receives a fixed amount of money from the central government, which was recently raised to $\mathrm{K} 1.5$ million. It was also discovered that in Rufunsa constituency, there was no fixed allocation to the Health and Education facilities. Therefore, very few Education and Health facilities have benefited from CDF funds. Moreover, most key informants interviewed raised a concern on the issue centred around tightening controls on the management and utilisation of the fund and enhancing accountability measures through enacting the CDF Act as opposed to managing it through the Local Government Act. This concern was raised because there was a feeling that the lack of information on the amount allocated to the education and health sectors indicates lack of transparency and transparency as most of the education and health administrators and other key stakeholder did not know the amount that the constituency had received for the past five years. Conclusively, the key informants and all beneficiaries' attested that the central government was not consistent in the disbursement of funds and that in few times that the funds were sent, they were delayed. Therefore, to foster sustainable rural development, the government of Zambia must put CDF allocations and funding at the top of the national agenda and should be the fundamental principle which underpins all national and rural policies that seek 
to mitigate underdevelopment through equal educational and health investments in enhancing people's wellbeing in rural setups.

The key objectives of the CDF fund are to fund projects with immediate social and economic impact of the citizens, with a view of improving lives, alleviating poverty and bringing general development (IEA, 2006). According to Kimenyi (2005), CDF is designed to fight poverty through the implementation of developmental projects at the local level, and particularly, those that provide basic needs such as education, healthcare, water, agricultural services, security and electricity. It must be noted that, up to date very few health posts and schools have been built and equipped through the CDF funds. CDF funds are there to help decongest larger district level hospitals (Ministry of Health, 2007). Furthermore, operational structure of the CDF allows local people especially in the rural communities to make their own expenditure decisions that reflect their tastes and preferences to maximize their welfare and benefits.

\subsection{Community Participation in CDF Projects}

According to Craig \& Mayo (1995), development can only be meaningful if the beneficiaries are allowed participation in community projects. Therefore, community participation, defined as a strategy for involving society in matters which concern them, is very vital in decision-making and sustainable rural development. This participation should be at all levels, that is from project identification right through to project implementation, monitoring and evaluation. One of the aims of the study was to examine the extent of community participation in the selection and implementation of projects on which CDF is utilised. In order for the researcher to establish whether a study into CDF would draw meaningful conclusions, it was important to discover if the community members have the knowledge and awareness if CDF existed in their communities and if it has helped in the education and health sectors in the past five years. The local endogenous people have the right to know the existing CDF projects in their local communities (their wards), for effective and relevant participation to take place. Community participation is likely to be effective when adequate information about all concerns on which their decisions and participation are required. Community awareness and knowledge can only be made obtainable through information dissemination policy, using all available media such as meetings, participatory sessions, radio, pamphlets and drama among others (Kumar, 2002).

The data obtained showed that out of 10 health staff only (10\%) have never heard of CDF while $(90 \%)$ were aware of CDF. On the other hand, $100 \%$ of both the education staffs and administrators have heard of CDF. However, from the beneficiaries' side, the results show that 40 out of 58 beneficiaries have heard about CDF while 18 were not aware of CDF. The findings show that majority of the respondents knew or had heard about $\mathrm{CDF}$ as demonstrated in the information above. The higher level of respondents' knowledge of CDF could be linked to higher civic education knowledge that go hand in hand with the level of awareness coupled with the fact that CDF disbursement is their engagement. This can also be linked to the fact that under the new $C D F$ Act, community knowledge and awareness is prerequisite in order to achieve the desired results.

Figure 2 below shows responses of community members' knowledge, awareness and participation in and about various aspects of CDF.

Figure 2: Responses showing Community Knowledge, Awareness \& Participation in CDF Aspects

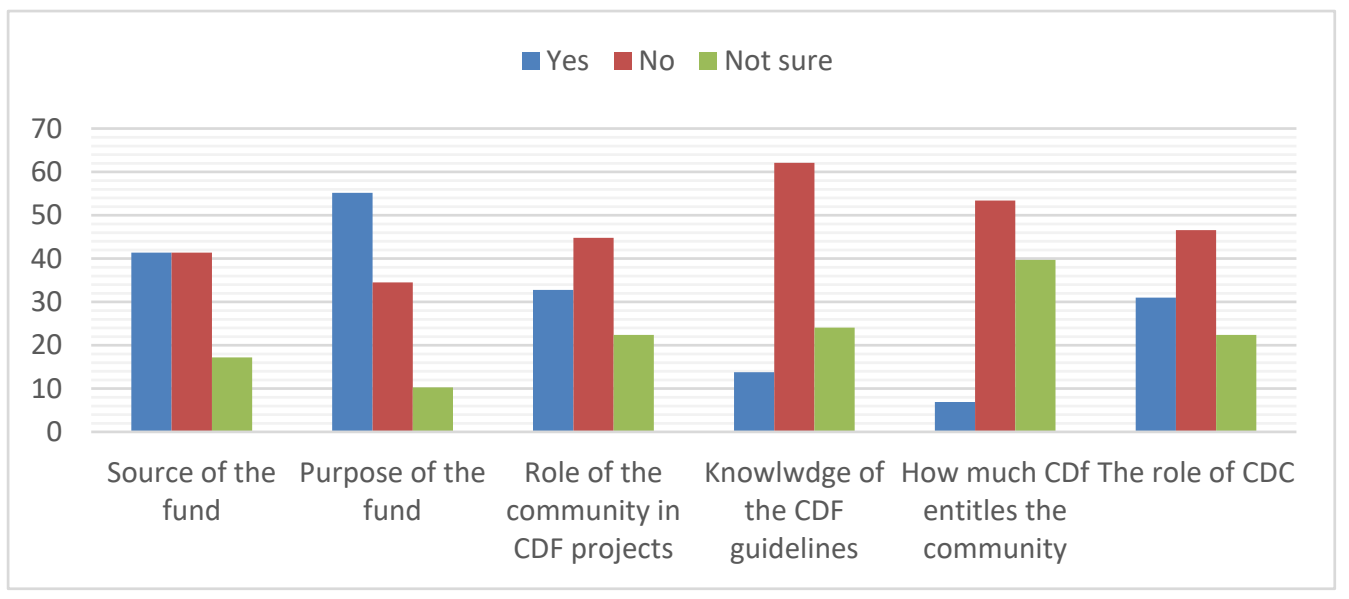

Source: Survey Data (2020)

Figure 2 above reveals that the majority of the respondents (40\%) indicated that they did not know the details surrounding the source of CDF while $40 \%$ again agreed to have known the source of the fund. Whereas $55 \%$ knew about the purpose of the fund, 35 $\%$ did not know, $10 \%$ were not aware at all of the purpose of the fund. The bigger percentage of the beneficiaries (45\%) were not aware about the roles of the community in CDF project whereas $60 \%$ did not have knowledge of the CDF guidelines. Furthermore, majority of the respondents did not know how much CDF their constituency was entitled to.

Therefore, from the above analysis, most of the beneficiaries were unaware of the channels of disbursement of the fund and what the fund was intended for. The level of knowledge about the source of the fund was very low by the beneficiaries. The interview with beneficiaries revealed that the entire education and health facilities administrators and staffs did not know how much 
they were entitled from the fund in their constituency. Most of the people agreed that they did not know the roles of the constituency development committees and how CDF was appropriated and disbursed. The ward councillors and CDFC attested that most of the local people do not know about the new CDF guidelines as they are still working on it. However, the levels of knowledge about basic information concerning CDF were found to be quiet high. One beneficiary stated that:

"I have heard of CDF and it is a good thing but it is not doing enough. I don't know where the money comes from but the MP brings it here to help the people and uplift their living standards"(View expressed by a beneficiary in Nyangwena ward on 7 May 2020)

This lack of knowledge by many beneficiaries on the source of CDF in the community points out the limited knowledge that the people at grassroots have with regards to this participatory tool of development. Therefore, there is need for more civic education and sensitisation about central government and the disbursement of CDF led by MPs, councillors and the district council that should involve the local community.

The study also wanted to know the level of community participation in decision making for the improvement of health and education facilities service delivery and if they were aware of how decisions were arrived at. With this in mind, respondents were asked to respond to whether they had been involved in various selection and implementation of CDF projects. Respondents were also asked to indicate how the decisions were made and how many meetings they had with the number of community members in attendance. The response indicated that the majority of the beneficiaries (77.6\%); 80\% Health administrators; $90 \%$ health staff; $60 \%$ education administrators, and $80 \%$ of the education staff are generally not aware of how decisions were arrived at in funding the health and education facilities using the CDF. Results further confirm that the entire sampled group was not sure who made the decision on improving either the health or education sectors in the constituency. However, $22.4 \%$ of the beneficiaries, $80 \%$ of the education key informants and $70 \%$ education staff revealed that some meetings were held attended by between 80 to 150 community members. However, only education facility staff responded much in affirmation that the meetings were held whereas the health facility staff response was low. This entails that there is need for community meetings to be made more public and all other stakeholders to be invited to these meetings.

In Zambia, Members of Parliament have CDF money overspent, misappropriated and misapplied from the CDF bank accounts. This leads to incomplete projects and lack of beneficiary benefits. A case in point is the case of Rufunsa Constituency where about K1.3million was fraudulently withdrawn and diverted by the officials of the Ministry of Local Government and housing in December 2013 (Zambia Daily Mail, 2015). Similar cases have led some of the other MPs to lose or fail to retain their seats. This further points out that the success of the fund is pegged on the character and the commitment of the area MP to use the fund for general development in his/her constituency as prescribed by the Act.

According to Okungu (2008), a political analyst, $70 \%$ of the constituencies have reported mismanagement, theft, fraud and misappropriation and that $\mathrm{CDF}$ issues are of a political nature.
Ongoya and Lumallas, (2005) are of the view that, CDF has the potential of being used by politicians to build their reputation in their constituencies and mobilize political support. As it were, the fund has no specific development agenda; hence, it stands out as a political tool (Gikonyo, 2008).

Community participation in monitoring and evaluation is generally a vital ingredient used in determining effective implementation of any development project and the quality outcomes. Conferring to Mwabu (2002), beneficiaries may determine the success or failure of any project. For Mwabu (2002), involving the community, the development workers stand high chances of identifying the vital needs of the community as well as the solutions to the challenges that could act as stumbling block to the success of their intervention. To this end, the entire respondents were assessed whether they have ever participated in the implementation, monitoring and evaluation of projects funded by CDF in the health or education sector, or if they had previously participated in one or more. Figure 3 below gives details of the findings. The distribution illustrated in figure 4.2 , very clearly shows that the majority of the beneficiaries, Education and Health administrators and staffs were not engaged in the implementation, monitoring and evaluation processes. The study also reveals that out of 51 beneficiaries who responded to this particular question, 46 said they have never participated while 5 said they had participated. 10 out of 10 health and education administrators, 9 out of 10 health staff and 7 out of 10 education staff declined to having participated in the monitoring and evaluation process. However, only 1 health staff and 3 education staff said yes to participation only in implementation, monitoring and not evaluation of CDF projects. This raises an issue on the level of competence needed in implementation, monitoring and evaluation process. Ordinarily, one would expect more of Health and education facility administrators and staffs to be involved since this is a health and education concern but this is not the case in Rufunsa Constituency. This might be the reason why projects in the education and health facilities do not meet the standards for the purpose i.e. quality and extent of improvements. Furthermore, if the beneficiaries, health and education administrators and their staff are not involved in the implementation, monitoring and evaluation processes, it implies that community members who are the major beneficiaries of the CDF projects have been side-lined as confirmed by results in figure 3 below.

Conversely, it is a fact that members of the community are not welcomed in the technical aspects of monitoring and evaluation processes. The results for not involving community members may be attributed to the fact that project evaluation requires specific technical knowledge, which may be missing among most of the beneficiaries and some Health and education Facility Administrators and staff. Mulwa (2007) agrees to the above by stating that an independent and competent body should carry out project evaluation in order to ensure a professional monitoring and evaluation process. The approach is meant to assess the consequences of the project on the beneficiaries such as whether the project is the right one for the beneficiaries or not. The government needs to have independent structures at the grassroots to monitor the progress of developmental projects and put in place strong measures to curb corruption and misappropriation of CDF funds. 
Figure 3: Level of Community participation in Implementation, Monitoring and Evaluation of CDF projects

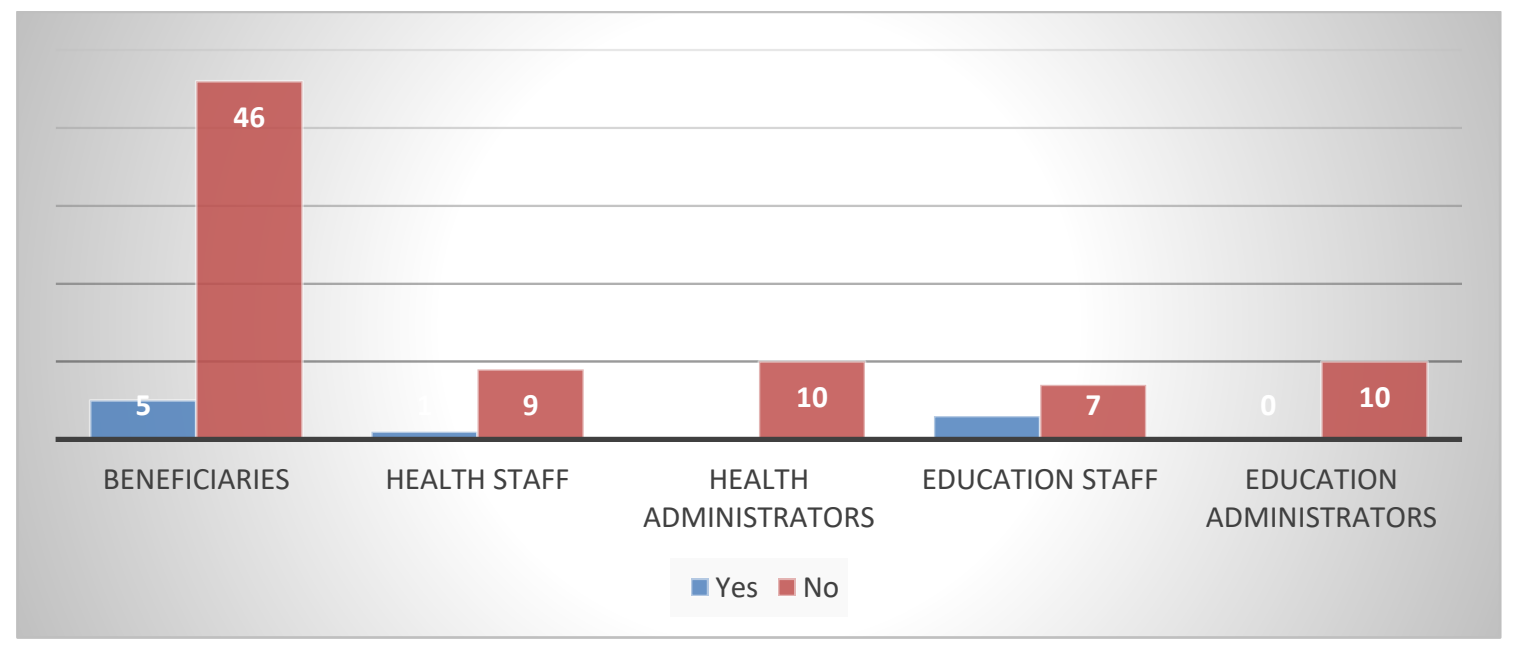

Source: Survey Data (2020)

According to Paul (1987), community participation refers to an active process by which beneficiary client groups influence the direction and execution of a development project with a view to enhancing their well-being in terms of income, personal growth, self-reliance or other values they cherish From the Zambian context, Caritas Zambia (2016), in agreement with the foregoing, observed that community participation in the CDF projects, in most cases, was not in line with the provisions of the CDF Guidelines. This variance in the levels of participation has resulted in partisan attitudes which tend to influence project identification, selection and implementation. Since the projects are not prioritized within the local rural communities' needs, and also that the CDF amounts are inadequate as constituencies are large in geographical size, it is noted that the projects do not benefit the rural communities (Caritas Zambia, 2016). World Health Organisation (2002) commenting on both health and education in improving the lives of rural people, indicate that rural development in health and education sectors can only succeed through concrete and effective community action. At the heart of this process is the empowerment of communities, their ownership and control of their own endeavours and destinies (WHO, 2002). Thus, beneficiary participation offers new opportunities for creative thinking and innovative planning and development.

Capacity building and training in rural communities about CDF development projects to arouse awareness and knowledge is of utmost importance. Training is a process by which individuals gain knowledge, skills and attitudes that are helpful in shaping the lives of the people. Imparted skills and knowledge are important in solving emerging problems and challenges especially in health and education (ZIPAR 2015:3-4, Banda 2019). Gitonga (2010) enlightens that when the rural members of a society increase their personal knowledge, awareness and management of resources, rural sustainability and just distribution of resources will be attained. Through the acquired knowledge, abstract theoretical constructs are tested with real life challenges, hence the educated always take control of events with courage. Education brings about awareness and knowledge thus moulding the behaviour of individuals into a desired state. This offers opportunities for innovation and creativity necessary in addressing both current and future challenges.

\subsection{Impact of CDF on Health and Education Service Delivery in Rufunsa Constituency \\ 2.1.1. Education Sector}

One of the ways of determining rural development in the study area was to establish if CDF has contributed to education facilities / infrastructure development in the past five years. Existence of rural education facilities and also the distance to the nearest learning institution are major factors in curbing illiteracy. The study focused on the availability and accessibility of schools to rural communities. To this end the study targeted the education administrators and Staff to indicate the distance to the nearest school or education facility as they are in the better position to state absolutely.

On the question of distance to the nearest school, it was very evident that pupils need to walk long distances (above 10 kilometres) to the nearest school as most education facilities were far away from their homes. In terms of the nearest school, $60 \%$ of the education administrators, $40 \%$ of education staff and $32.8 \%$ of beneficiaries indicated that the nearest school was $5-10 \mathrm{~km}$ away whereas $20 \%$ education administrators, $30 \%$ education staff and $19 \%$ of the beneficiaries said that the nearest school was between $0-5 \mathrm{~km}$ away. This indicates that schools were not near pupils' homes. Further interrogation of the key informants during the study indicated that the few schools that were available lacked the necessary tools to foster better service delivery of education. Most schools lacked manpower (teachers) and facilities such as furniture or desks, computers, essential text books (English, Mathematics and Science) to offer quality education to students. On teachers in schools, $60 \%$ of the education staff said that the teaching staff's facilities were not enough. This is evident as the teacher ratio for education staff is 1-125. This is true as the researcher found that at one school, Kalungula primary school, there were only two teachers i.e. the Head Master and one teacher. Thus the above ratio could be true. Most schools in the Constituency had not received teachers, thus, continued experiencing shortages. The availability of teachers in the sampled 
3 secondary and 11 primary schools were another indicator of education quality status of rural schools. As such from the teacher student ratio of 1-125 where it is supposed to be 1-45 as normal class room. This shows that teaching staff in most learning institutions were not enough implying that there was a challenge when it came to teaching students due to a wide range of teacherstudent ratio.

The study further established that most schools in Rufunsa area did not have enough reading materials as findings show that
$50 \%$ of the teaching staff stated that 1 book is shared among 10 or more pupils (Ratio: 1-10) hence hindering effective learning. The reasons for lack of enough reading materials include government's failure to purchase books in the schools, the schools had not received any CDF towards improving education service delivery and parent's inability to buy their children books due to high rates of poverty. Furthermore, more schools lacked computer classes and computers too.

Table 1: Are Education facilities enough after introduction of CDF?

\begin{tabular}{lllll}
\hline Facility & Enough & Not enough & Shortage & Don't know \\
\hline Classrooms & 3 & 25 & 13 & 17 \\
Laboratories & 1 & 19 & 25 & 11 \\
Libraries & 1 & 14 & 23 & 20 \\
Offices & 2 & 24 & 12 & 18 \\
Dormitories & 2 & 4 & 33 & 20 \\
School vehicle & 1 & 2 & 35 & 20 \\
Computer laboratory & 1 & 4 & 33 & 18 \\
\hline
\end{tabular}

Source: Survey Data (2020)

The entire sampled population who are beneficiaries and education staff said that classrooms in schools were not enough. Twenty-five (25) beneficiaries and $50 \%$ of the education staff said that the classrooms were not enough. The essential science laboratories, home economics, library stocks, functional computers and multi-purpose halls were also not enough. Furthermore, sporting facilities and equipment like netballs, footballs, chess boards were not enough, in fact in all primary schools sampled. This implies that the existing education facilities in Rufunsa Constituency did not meet provision of quality education service delivery to students.

\subsubsection{Health Sector}

The study also investigated if CDF has helped in bringing health facilities closer to the homes of the rural people through reduction on the walking distance by the patients in the constituency. Both the beneficiaries and the health staff were asked to indicate the distances to their nearest health facility. Table 2 below shows the results:

Table 2: Distance to Nearest Health Facility (In Kilometres)

\begin{tabular}{lllllll} 
& Beneficiary & & \multicolumn{2}{c}{ Health Administrators } & Health Staff \\
\hline Distance & Frequency & Percentage & Frequency & Percentage & Frequency & Percentage \\
\hline $0-2$ & 9 & 15.5 & 2 & 20 & 3 & 30 \\
$2-5$ & 11 & 19 & 2 & 20 & - & - \\
$5-10$ & 22 & 37.9 & 4 & 40 & 5 & 50 \\
10 above & 16 & 27.6 & 2 & 20 & 2 & 20 \\
\hline Total & $\mathbf{5 8}$ & $\mathbf{1 0 0}$ & $\mathbf{1 0}$ & $\mathbf{1 0 0}$ & $\mathbf{1 0}$ & $\mathbf{1 0 0}$ \\
\hline Average & & $\mathbf{7 . 8}$ & & $\mathbf{7 . 4}$ & & $\mathbf{7 . 6}$ \\
\hline
\end{tabular}

Source: Survey Data (2020)

Analysis in Table 2 above indicates that majority beneficiaries $39.7 \%$ walked between $5-10 \mathrm{~km}$ to access the nearest health centres and health posts for treatment. Just like the $39.7 \%$ beneficiaries who said the distance to the nearest health facility was $5-10 \mathrm{~km}$, the health facility staff, about $50 \%$, and $40 \%$ administrators also stated that the distance to the nearest health centre or post for people was between $5-10 \mathrm{~km}$. This can be said to be the true picture because the health staff know exactly where the next health facility is located and also the boundaries of the health facilities. Therefore, average walking distance to health centres is 7.8 kilometres for the beneficiaries while the average walking distance from the health administrators is 7.4 kilometres with the average walking distance to the health facilities staff being 7.6 kilometres.
According to the Ministry of Health, they recommend that, every after 5 kilometres there should be a health facility. This compares favourably with the World Health Organization's recommendation of 2.5 kilometres to a nearest health facility in the rural areas. Thus based on the above analysis, the people of Rufunsa constituency have to walk on average more than 7 kilometres to access health care services. Additionally, the entire key informants agreed that there is shortage of health staff and health facilities (like Chiyota and Kazemba health posts, there is only one trained health personnel on each health post managing all health related work). Because of shortage of health staffs, most patients take a long time before accessing treatment, which is detrimental to sustainable health living. 
Furthermore, in evaluating the impact of CDF on health status of people in Rufunsa Constituency, the study sought to establish whether the various health equipment like, ambulance services, drugs, medical equipment and machinery, health workers, maternity wards and mortuary services in government health centres after the introduction of CDF were available and accessible by the local people. Towards this goal, Table 3 gives the summary of the findings on the availability and accessibility of health facilities equipment.

Table 3: Showing the beneficiary response on the Availability and Accessibility of health equipment's

\begin{tabular}{lllllllllllll} 
& \multicolumn{2}{l}{ Available } & \multicolumn{2}{l}{ Not available } & \multicolumn{2}{l}{ Partially } & \multicolumn{2}{c}{ Accessible } & \multicolumn{2}{c}{ Not Accessible } & \multicolumn{2}{c}{ Partially } \\
\hline & Freq & $\%$ & Freq & $\%$ & Freq & $\%$ & Freq & $\%$ & Freq & $\%$ & Freq & $\%$ \\
\hline Ambulance services & 21 & 51.7 & 20 & 34.4 & 2 & 3.4 & 15 & 25.9 & 9 & 15.5 & 3 & 5.2 \\
Drugs & 21 & 36.2 & 10 & 17.2 & 11 & 18.9 & 16 & 27.6 & 10 & 17.2 & 4 & 6.9 \\
Medical Equipment & 12 & 20.7 & 19 & 32.7 & 10 & 17.2 & 8 & 13.8 & 13 & 22.4 & 7 & 12 \\
Health Machines & 12 & 20.7 & 23 & 39.6 & 5 & 8.6 & 4 & 6.9 & 16 & 27.6 & 7 & 12 \\
Health & 25 & 43.1 & 10 & 17.2 & 8 & 13.8 & 12 & 20.7 & 9 & 15.5 & 6 & 10.3 \\
$\begin{array}{l}\text { Staff/Workers } \\
\text { Maternity Wards }\end{array}$ & 26 & 44.8 & 13 & 22.4 & 1 & 1.7 & 18 & 31 & 9 & 15.5 & 1 & 1.7 \\
Mortuary & 2 & 3.4 & 23 & 39.6 & - & - & 2 & 3.4 & 24 & 41.4 & 2 & 3.4 \\
\hline
\end{tabular}

Source: Survey Data (2020)

The above summary was done due to the fact that most developing countries and rural health facilities have challenges to availability and accessibility of quality health services delivery. Every health centre needs to have ambulance services in attending to emergency cases of patients. However, during the study majority of about $51.7 \%$ of the respondents revealed that there are ambulance services whereas $34.4 \%$ of the respondents said that ambulance services lacked in health facilities. In fact, the health staff said there is only one ambulance that covers the three zones in the constituency. This means that in case of sickness, residents looked for their own means of transport to take the sick to the nearest health centres or hospital. The one ambulance service did not have enough first aid equipment and this could lead to death of some patients before they get to the health centre or hospitals. The reason for one ambulance service is due to the capacity of health facilities, which are mostly small and do not handle complex health cases. Although ambulance services still lack in health centres, the services offered have slightly improved.

The study further revealed that there were few health practitioners attending to patients especially in the health posts.
This was reported by $81.5 \%$ of the respondents. This implies that most health challenges among the residents in the Constituency were not addressed. Only $19.5 \%$ argued that health practitioners were enough and available to attend to patients. On the mortuary, medical equipment and machines in the health centres, $39.6 \%$ of the respondents said that there are no medical equipment and machines while $20.7 \%$ said that they were available in hospitals. It must be noted that during the research, it was discovered that the whole Rufunsa district has only one small mortuary from Mpanshya Mission Hospital. This means that most of the health facilities had inadequate medical equipment and machines. In a nutshell, the health status of residents in the Constituency were mildly improving after the introduction of CDF. The public health facilities available by that time did not have adequate building or structures, health workers, drugs, and ambulance services to facilitate service delivery to the residents of the Constituency. On the other hand, the influence of CDF allocation on health care was assessed by asking the beneficiaries to rate the health care services in the health facilities in the past five years and figure $\mathbf{4}$ gives a summary of the findings.

Figure 4: Beneficiary responses on the Rate of Health Care Service Delivery in the past five years

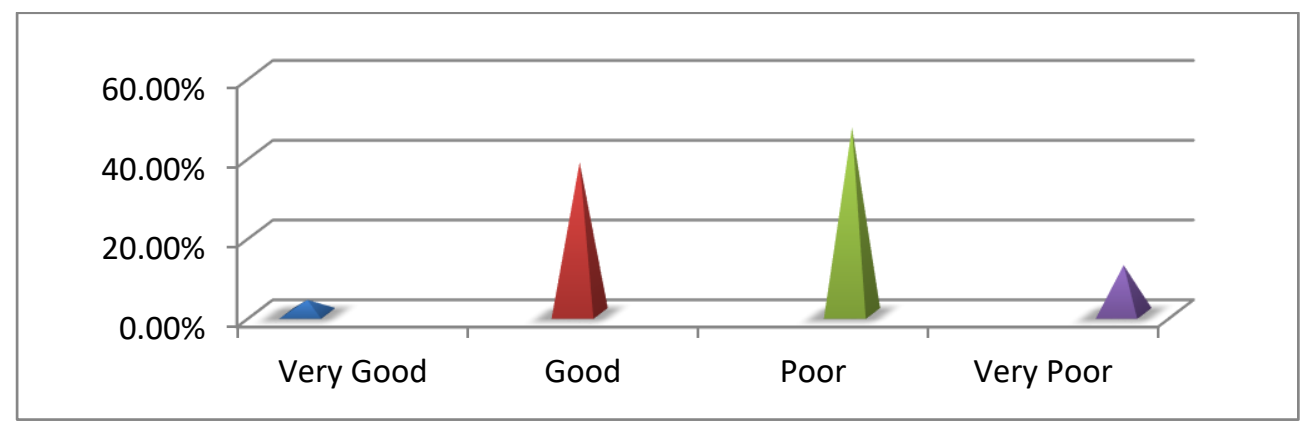

Source: Survey Data (2020)

Figure 4 above gives a summary on the health care and service delivery status in Rufunsa Constituency. The beneficiaries are of the view that the health services have not been very good as
$46.6 \%$ said that the health care service were poor as compared to $37.9 \%$ of the beneficiary who responded that the health care services were good. Only $3.40 \%$ said that health facilities were 
very good which is contrary to the $12.10 \%$ who said that the health care services were very poor. Generally, the health service can be said to be poor. This, therefore, means that people concerned with the management of the CDF still have a lot to do so that all parties can be happy.

The study was also interested to understand how health facility administrators and staff in the Constituency perceive health services provided in government health facilities in the Constituency since the introduction of CDF. Thus, both the health administrators and health staff were asked to rate the availability and accessibility of the health facilities in the past five years. The responses are summarized in Table 4 below:

Table 4: Rating of health services in the constituency after introduction of CDF

\begin{tabular}{|c|c|c|c|c|}
\hline & \multicolumn{2}{|c|}{ Health ADM } & \multicolumn{2}{|c|}{ Health staff } \\
\hline & \multicolumn{2}{|c|}{ Availability \& Accessibility } & \multicolumn{2}{|c|}{ Availability \& Accessibility } \\
\hline & Frequency & $\%$ & Frequency & $\%$ \\
\hline Low $0-39 \%$ & 2 & 20 & 1 & 10 \\
\hline Moderate $40-60 \%$ & 5 & 50 & 7 & 70 \\
\hline High $70-80 \%$ & 3 & 30 & 2 & 20 \\
\hline Excellent $80-100 \%$ & - & - & - & - \\
\hline
\end{tabular}

\section{Source: Survey Data (2020)}

As shown in table 4.2 above, five health administrators $50 \%$ and seven health staff $70 \%$ were of the view that the services offered in health facilities are moderate (40-60\%) to high (70$80 \%$ ) respectively. However, 2 health administrators $20 \%$ and 1 health staff $10 \%$ maintained that the services were low (0-39\%) and none of the health administrators and staff agreed that the services offered in the facilities were excellent. The data indicate that health services offered in these health facilities were moderate thus has improved since the introduction of CDF and in the past five years. On the contrary to the argument that CDF has not improved health services in the area of study, it is attributed to insufficient and poor infrastructure (buildings and roads) in the rural areas, lack of ambulance services and insufficient drugs in the health facilities as discussed above.

The study revealed that health facilities were not enough in the Constituency. These facilities also did not provide comprehensive health care and service delivery because they had insufficient health machines, health staff and workers, maternity wards, mortuary and important medical equipment. Therefore, inadequate buildings posed a great challenge in the health sector in the Constituency. Nevertheless, it is not surprising that respondents for those facilities were quick to note some little improvements ranging from increased number of mother's shelters and drugs for health facilities. Accordingly, 30\% of health administrators and $40 \%$ of the health staffs said that, CDF has been used to improve the maternity ward and mother's shelters for some health centres. Most health facility equipment are not enough, only $60 \%$ administrators and $40 \%$ health staffs said that dispensary and drugs in health facilities had improved. Number of new wards, laboratories, additional medical personnel (human resource and wards had not improved at all by the CDF).

\section{CONCLUSION}

Education and health services stand at the centre of human development and their availability, accessibility, utilization, affordability and equitability are of paramount importance. In the case of health and education facilities and service delivery in Rufunsa Constituency from the perspective of CDF funding, there is a clarion call for government's enhanced consistency in prioritising the allocation and consequential timely disbursement of the fund to the constituency for collectively agreed upon community development ventures annually. The current scenario where the constituency has only received twice (totally $\mathrm{K} 2$, $150,000.00$ i.e. $31 \%$ ) out of five times for the past five years leaves a lot to be desired and clearly explicates the glaring underdevelopment documented herein. By implication, the constituency has been robbed of K4,850,000 deserved development fund for the community's socio economic wellbeing. On the other hand, community involvement in development projects is the surest strategy of achieving sustainable rural development. The beneficiaries should be involved in projects identification, design, implementation, monitoring and evaluation processes though this requires capacity building, which should be factored by planners and policy-makers including civic leaders. The knowledge and awareness of CDF guidelines, channels of funds and when the funds are available is important information which the community must not be deprived of pursuant to the CDF legal framework as injuncted in Act No. 11 of 2018.The selection, planning, preparation and implementation of development projects should centralise the beneficiaries as owners of the same. This will make the CDF resources bring about desirable transformation through the health and education sectors in the constituency. These issues also call for attention to address the budgetary implications in facilities and servicing which foster rural development in Rufunsa Constituency.

\section{REFERENCES}

[1] Banda, M. (2019). Community Mobilisation and Collective Action Module. Lusaka: Cavendish University of Zambia.

[2] Caritas Zambia. (2011). A study report on the constituency development fund: allocation disbursement and utilisation. Lusaka: Zambia Episcopal Conference.

[3] Chileshe, A. (2011). The Impact of Constituency Development Fund in Zambia. (Abstract) Economics Association of Zambia. [Online] Available from: $\quad$ http://www.nai.uu.se/ecas-4/panels/61 80/pane173/Alexander\%20Chileshe\%20-\%20Abstract.pdf.

[4] Central Statistical office (2010) Census of Housing and Infrastructure. 
[5] Gikonyo, W. (2008). The CDF social audit guide: A handbook for communities. Open Society Initiative for East Africa, Nairobi.

[6] Gitonga. B. A. (2010). Project Management Simplified: Community Development Project.

[7] Government Republic of Zambia. (2018). Constituency development Fund Act No. 11, Section I. 2018.

[8] Government Republic of Zambia. (2002)., "The National Decentralisation Policy: Towards Empowering the People", Lusaka, Office of the President.

[9] Government of Zambia. (2006). Lusaka District Development Plan, 20062011. Lusaka: LCC.

[10] Government Republic of Zambia. (2006). Revised Guidelines on the Management and Utilization of Constituency Development Fund, Ministry of Local Government and Housing, Lusaka

[11] Government of the Republic of Zambia. (2006b). Revised guidelines on the management and utilisation of Constituency Development Fund

[12] Government of the Republic of Zambia. (2006a). Fifth National Development Plan 2006- 2010. Lusaka: Government Printer.

[13] Government of the Republic of Zambia. (2006). Guidelines on the management and utilisation of Constituency Development Fund. Lusaka: Ministry of Local Government and Housing.

[14] Government of the Republic of Zambia. (2006b). Guidelines on the management and utilisation of constituency development fund. Lusaka: Ministry of Local Government and Housing.

[15] Hobo T. (1996) Endogenous Development and Rural Villages in Japan, Iwanami Shoten

[16] IAMO, (2007). Sustainable rural development: What is the role of the agrifood sector? Volume 39, Martin Petrick and Gertrud Buchenrieder (ed).

[17] Institute of Economic Affairs (IEA) (2006). Fiscal decentralization in Kenya, priority issues for consideration: Policy brief issue no.6.

[18] JICA. (2004). Approaches for systematic Planning of development projects (Higher Education). https://openjicareport.jica.go.jp/pdf/11702651_01.pdf

[19] Kaduuli, S .(2008). Fighting poverty through parliament. Africa Leadership Institute: York University.

[20] Kemp, A., Faust, J. \& Leiderer, S. (2005). Synthesis report Between high expectations and reality: An evaluation of budget support in Zambia.

[21] Kimenyi, M, S. (2005). Efficiency \& Efficacy of Kenya's Constituency Development Fund. Theory and Effidence: Economics Working Papers. [Online] Available from http://digitalcommons.uconn.ed/econ_wpapers/200542. [Accessed 20 December 2019].

[22] Ministry of Health. (2007). Zambia demographic and health survey. Lusaka: Central Statistical Office.

[23] Ministry of Local Government and Housing. (2006). Guidelines on the Management and Utilisation of Constituency Development Fund, 3rd edition. Lusaka: Republic of Zambia.

[24] MoGE. (2019). Ministerial Statement to Parliament - School Fees Reduction in all Public Schools in Zambia. Lusaka: MoGE.

[25] Mugenda, O. M and Mugenda A. G. (2003). Research Methods: Qualitative and Quantitative Approaches (Revised edition). Nairobi: Acts Press.

[26] National Assembly of Zambia, (2012). Constituency development fund, Zambia. Lusaka: Research Unit.

[27] Ogao, E. (2019). Development Theory and Perspectives, Kenya: Catholic University of East Africa.

[28] Ongoya, Z.E \& Lumallas, E. (2005). A Critical Appraisal of the Constituency Development Fund ACT: Nairobi, Kenya.
[29] Okungu. J. (2008). The Beauty and Shame of Kenya's Constituency Development Fund, Nairobi: Afro African Articles.

[30] Olinto, P. \& Uematsu, H. (2010). The State of the Poor: Where are the Poor and where are they Poorest. The World Bank: Poverty Reduction and Equity Department.

[31] Pellissery, S (2012). "Rural Development". Encyclopedia of Sustainability. 7: 222-225. [Online] Available from: https://medcraveonline.com/SIJ/SIJ03-00157.pdf. [Accessed 20 December 2019].

[32] Phiri, P. (2016). Community participation in constituency development fund (CDF) project in Zambia city. The case of Kanyama Constituency. Lusaka: The University of Zambia, Lusaka. [Masters Dissertation].

[33] Polit, D., \& Hungler, B. (1997). Essentials of nursing research: methods, appraisal, and utilization. Philadelphia, Pennsylvania: J. B. Lippincott Company.

[34] Republic of Zambia. (2012). Report of the Auditor General on the Management of Constituency Development Funds and Grants to Local Authorities for the Financial Year Ended 31st December 2012. Lusaka.

[35] Silvius, A. G., \&Schipper, R. (2010, November). A maturity model for integrating sustainability in project and project Management. In 24th World Congress of the International Project Management Association. IPMA Istanbul.

[36] Todaro, M.P, and Stephen Smith. (2015). Economic Development (12th Ed). New

York: Pearson.https://mediasrv.aua.gr/eclass/modules/document/file.php/AOA215 /Economic\%20Development\%20-\%20Todaro\%20and\%20Smith.pdf

[37] Todaro, M. P \& Smith, S. C. (2011). Economic Development. 11th ed. United Kingdom: Addison-Wesley.

[38] UNESCO - Zambia (2018). Annual Report - 11th Ed. Lusaka: UNESCO.

[39] World Bank. (2001a). Rural Development Strategy: (http://wbln0018.worldbank.org/essd/rdv/vta.nsf/Gweb/Strategy) [Accessed 1 August 19]

[40] Zambia Daily Mail Limited, (2016) (Chomba Musika), CDF- Funded structures weak Veep. Lusaka. [Online] Available from: www.dailymail.co.zm/cdf-funded-structure-weak-veep/. [Accessed 28 July 19].

[41] Zambia Daily Mail Limited. (2015). (Jimmy Chibuye) 2 Testify in Rufunsa CDF case, Lusaka. [Online] Available from: www.daily-mail.co.zm/2testify-rufunsa-cdf-case/. [Accessed 28 July 19].

[42] Zambia Institute for Policy Analysis and Research (ZIPAR), (2015), The Management of the Constituency Development Fund. [Online] Available from: http://www.zipar.org.zm/research/our-publications/parliamentarysubmissions/35-the-managemnet-of-the-constituency-developmentfund/file. [Accessed 25 July 19]

\section{AUTHORS}

First Author - Chrine, C. Hapompwe, Lecturer; Cavendish University Zambia, Faculty of Arts, Education \& Social Sciences, chapompwe@cavendish.co.zm

Second Author - Mabvuto Nanias Tembo, Post Graduate Student; Cavendish University Zambia, Department of Development Studies, mavutotembo@gmail.com

Third Author - Elizabeth Zyambo, Head of Department; Cavendish University Zambia, Faculty of Business \& Information Technology, emunengami@cavendish.co.zm 